-Journal Publications . Research Consultancy

\title{
PURCHASE BEHAVIOUR OF INDIAN CUSTOMERS TOWARDS ENVIRONMENT FRIENDLY MOTOR VEHICLES
}

\author{
MAKARAND UPADHYAYA \\ Associate Professor-Marketing, University of Bahrain \\ (AACSB) Accredited Business School, Department of Management \& Marketing, \\ College of Business Administration, Kingdom of Bahrain
}

\begin{abstract}
At the present time lot of customers in India are buying environment friendly motor vehicles like hybrid and electric vehicles. Therefore, this study was performed to recognize the factors that influence the purchase intention of buying environment friendly motor vehicles among Indian customers. Information is collected from 125 vehicle owners using a structured questionnaire. According to regression analysis, awareness of environment friendly motor vehicles, environmental familiarity and subjective norms has a considerable influence on purchase intention of environment friendly motor vehicles in India.

KEYWORDS: Environmental, Hybrid Vehicle, Electric Vehicle, Purchase Intention \& Motor
\end{abstract}

Received: Sep 26, 2017; Accepted: Oct 16, 2017; Published: Oct 31, 2017; Paper Id.: IJMPERDDEC201712

\section{INTRODUCTION}

Due to global warming a lot of devastating effects can be seen such as ice caps melting, rising sea levels, death of coral reefs and sea species, thus due to this environment conversation has become one of the most demanding and a critical issue in the $21^{\text {st }}$ century. (UNEP [1], 2012). Due to green house air emission like carbon dioxide, nitrous oxide and mithane 2015 was recorded as the hottest year ever as mentioned by National Geographics. (Untion of Concerned Scientists, 2014). In 2013 the transport industry contributed to most of the green house emissions. (Eurostat,2013). The fossil fuel which is a non-renewable resource is used for transportation and due to this they are depleting on a fast pace. To keep the environment safe there has been a lot of talks going on within the societies to use green transportation as an alternative to fuel as these are less harmful for the environment.

To stop these emissions and keep our environment safe from degradation technology advanced vehicles like "Hybrid" Cars are coming out in the market and it's an estimate that the demand for these vehicles would touch an all-time high because these vehicles use fuel as well as electricity and thus conserve the environment from being polluted. The worldwide sale of these hybrid cars are 4, 50, 000 as estimated by US department of motor traffic. In the year 2010 the number of imported vehicle was just 438 but it raised steeply to 5927 in 2011 as India has the maximum exports noted up top $1250 \%$ which is an extraordinary progress when compared to 2010, despite of raising amendment of taxes. The number of electric and hybrid registration has grown to over $453 \%$ in 2016 as compared to 2015.

There are many reasons that customers are buying eco-friendly vehicles but the first aim to introduce these vehicles was to reduce air pollution and green gas emissions. As the amount of imports and purchases have 
rapidly increased in India, it leads to the objective of this paper that is why the Indian audience so widely purchasing the eco-friendly cars in India.

\section{LITERATURE REVIEW}

\section{Awareness of Eco-Friendly Vehicles}

"The ability of the human mind to recall and identify that the brand is eco-friendly" can be termed as customers' awareness about eco-friendly products. (Tseng \& Hung 2013). It was also found out that the customers' awareness about the brand was not based on the benefits it has on the environment but rather it was based on customers' expectations. The influence on the green brand perception is caused due to the awareness about eco-friendly products as found out by Ottman (2008) and Chen (2012), but later (Aman, 2012; Chahal, 2010; Suki et al., 2013) suggested that to increase the customers perception about green products it was important to educate the society first which would automatically lead to a change is the buying behaviour of the customer. On the another hand an Indian study done by Karunananayake \& Wnanainayake found out that the knowledge about hybrid vehicles does not have a significant impact on the buying intention of the customer.

\section{Environmental Knowledge}

As defined by (Fryxell \& Lo, 2003) the environmental knowledge is associated to the facts, ideas and relationship concerning the natural environment and ecosystems. The relationship between environment knowledge and green customer behavior is strong as mentioned by (Mostafa, 2007).

The effects of psychographic factors and their effects on green buying behavior were broadly examined and the most prominent factors considered among all physiographic factors were environmental knowledge (Barr, 2007) and environmental concern (Tilikidou, 2007). The people who are environmentally concerned show more interest and intentions towards environment and their purchase intentions can be influenced. Most researchers also agree that people who show interest towards environmental responsive behavior are more likely at high stages of environment concern (Roberts \& Bacon, 1997) (Czap \& Czap, 2010). For e.g. it was found out in a research done by (Bang, Ellinger, Hadjimarcou, \& Traichal, 2000) that people who are more concerned with the environment are ready to pay more for renewable energy then those who are less environmental concern. Many researches done show a contracting result as it is found out the knowledge about environment or environmental concerns has a minor effect on environmental friendly behavior and concerns. As per a lot of studies done earlier the relationship between environmental concerns and ecofriendly behavior is extremely low. For instance the common attitudes are significant causes of definite behavior and thus due to environmental knowledge there is no direct influence on eco- friendly behavior and purchase. As earlier researches done on environmental concerns showed that there is just a minor difference between two. Thus it's worthwhile to study some more factors belonging to this dimension before concluding anything.

\section{Environmental Attitudes}

Attitude as defined is the gradually acceptable or unacceptable assessments, development and emotional state towards any object or hint. A straight and positive effect on customer's green purchase intention is termed as green environmental attitude. Attitude was the most important predictor of intentions as people with positive attitude towards environment show environmental friendly behaviour and concerns. 
The association between attitude and purchase intention is said to be stronger then the relationship between purchase intentions and real purchase behaviour. Thus it was found out the effect between attitude and purchase intention.

Attitude towards environmental benefit is projected to influence the consumer behaviour and Intention.. (Albayrak, Aksoy, \& Caber, 2013) ( Barber, Kuo, Bishop, \& Goodman, 2012) (Ellen, Wiener, \& Walgren, 1991). Environmental Attitude is used to measure the buyers purchase intention towards hybrid vehicles. But Karunanayake \& Wnanainayake found out that the purchase of hybrid vehicles is not dependent on environmental attitude of people. In terms of forecasting the sales of hybrid vehicles attitudinal reviews have frequently mixed. These reviews only suggest that customers purchase intention is due to the benefits of environment on society rather than actual purchase intentions. As a result of the feel well-intentioned responses for the green and advanced technologies, these reviews lean headed for overstate the demand for environmentally friendly automobiles (Gould \& Golob, 1998) (Kurani, Turrentine, \& Sperling, 1996).

\section{Subjective Norm}

The norms designed to measure the grade at which a significant want them to perform is called subjective norm as termed by Rivis \& Sheeran, 2003. The customers need to embrace the technology with their willingness happens due to Subjective Norms.

Several writers examine subjective norms which were found out by the studies on environmental friendly behaviour. The causes which lead to the purchase of environmentally friendly products was studied by Kumar 2012 , he found out that purchase intentions have not been subjected to purchase intentions. To become an eco-friendly consumer it's important to have high positive subjective norms as said by (Albayrak, Aksoy, \& Caber, 2013) (Ohman, 2011) (Ooi, Kwek, \& Tan, 2012) karunanayake \& wannianayake. But some originated this relationship to be insignificant or weak (Stanton, et al., 1996), The effect of subjective norms on creating intention exposed to be commonly weaker in prior readings than the effect of attitude (Ham, Jeger, \& Ivković, 2015) The study of Norris Krueger and his classmates (Krueger, Reilly, \& Carsrud, 2000) presented that subjective norms are not interrelated with the intention of persons to establish their own businesses. So the authors argue that the long-established connection between subjective norms and intentions indicates the likely presence of projecting effect of these factors, giving method to a strong inspiration for additional study.

\section{Price Perception}

One more way to observe customers' behavioural intentions is to evaluate their readiness to pay. Customers were more likely to select environmentally friendly products that were comparatively more expensive. According to (Griskevicius, Tybur, \& Van den Bergh, 2010) there is a positive relationships between price perception and community consumption and they only acknowledged green products that were more expensive (i.e. luxury green products). Similarly Karunanayake \& Wnaniyake and (Mostafa, 2007) also found that price is main inspiration on hybrid car purchased intention. The cost of a car comprises its purchase price and running expenses. Running expenses for hybrids are also usually higher. Is this price premium a reflection for hybrid buyers? $\mathrm{Ng} \&$ Paladino found that price is not a significant forecaster on green mobile buying in Australia.

The conceptual framework of the study is shown in Figure 1 


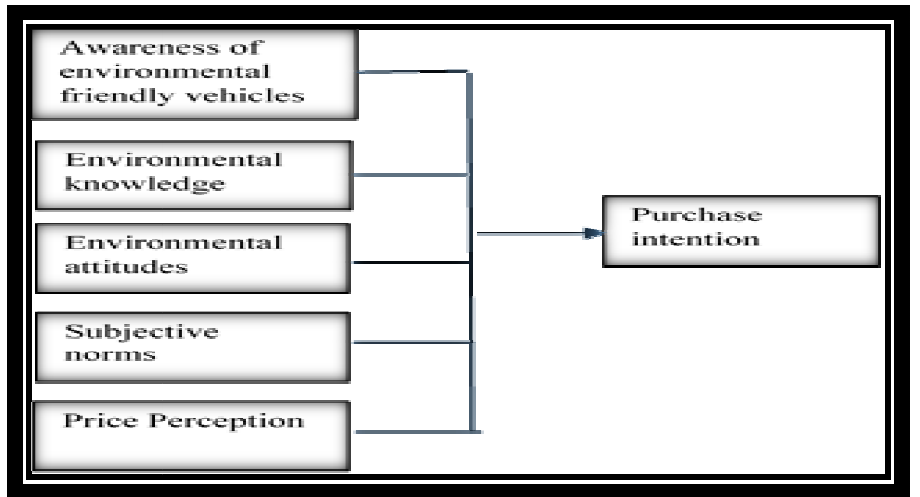

Figure1: The Conceptual Framework

Thus, the following hypotheses are derived based on the conceptual framework.

H1: Awareness of Eco - friendly vehicles has an influence on purchase intention

H2: Environmental knowledge has an influence on purchase intention

H3: Environmental attitude has an influence on purchase intention

H4: Subjective norms has an influence on purchase intention

H5: Price perception has an influence on purchase intention

\section{RESEARCH METHODOLOGY}

The quantitative approach was used in this study to analyse the data. Vehicle owners who are 18 years old were the target group for this study. A statistical analysis was used in this study as the population belonging to this Target group was unknown. Hence 106 were taken up as the desired sample size and 125 questionnaires were collected from cities of India based on the parking areas.

\section{DATA ANALYSIS}

A study was carried out to measure the reliability of the questionnaire.

The results are shown in the Table 1.

Table 1: Reliability Statistics

\begin{tabular}{|l|c|c|}
\hline \multirow{2}{*}{ Variable } & \multicolumn{2}{c|}{ Cronbach Alpha } \\
\cline { 2 - 3 } & Pilot Survey & Main Survey \\
\hline Awareness of environmental friendly vehicles & 0.765 & 0.656 \\
\hline Environmental knowledge & 0.721 & 0.789 \\
\hline Environmental attitudes & 0.892 & 0.765 \\
\hline Subjective norms & 0.734 & 0.767 \\
\hline Price Perception & $0.723^{*}$ & 0.789 \\
\hline I4 is removed-before remove 0.043 & \multicolumn{2}{|l}{} \\
\hline
\end{tabular}

The majority of respondents are male (68.3\%) with the age group between 18-30 years (53.6\%) old as shown by the descriptive statistics of the respondents. Many respondents earn an income less than Rs.50, 000 who hold the graduate degree and belong to Jaipur city.

The results are shown in Table 2. 
Table 2: Demographic Background

\begin{tabular}{|l|c|c|}
\hline \multicolumn{1}{|c|}{ Variable } & Frequency & \% \\
\hline Gender & 85 & \\
Male & 40 & 68.3 \\
Female & & \\
\hline Age & 67 & 53.6 \\
18-30 years & 30 & 24.0 \\
31-45 years & 22 & 17.6 \\
46-60 years & 06 & 04.8 \\
Over 60 years & & \\
\hline City & 48 & 38.3 \\
JAIPUR & 16 & 12.8 \\
ALWAR & 06 & 04.8 \\
KOTA & 10 & 08.0 \\
AJMER & 07 & 05.6 \\
BIKANER & 12 & 09.6 \\
UDAIPUR & 06 & 05.0 \\
CHITOOR & 06 & 05.0 \\
BILWARA & 05 & 04.2 \\
SIKAR & 05 & 04.2 \\
PILANI & & \\
\hline Educational Qualification & 14 & 11.2 \\
Up to High School & 33 & 26.4 \\
Up to Higher secondary school & 65 & 52.0 \\
Graduate & 13 & 10.4 \\
Postgraduate & & \\
\hline Income level & 59 & 47.5 \\
Below Rs.50,000 & 51 & 14.2 \\
Between Rs.50,000-100,000 & 08 & 06.7 \\
More than Rs.100,000 & & \\
\hline
\end{tabular}

The regression analysis was carried out to test the hypothesis derived.

The model summary shows in Table 3 .

Table 3: Model Summary

\begin{tabular}{|c|c|c|c|c|}
\hline $\mathbf{R}$ & $\mathbf{R}^{2}$ & Adjusted $\mathbf{R}^{2}$ & Std. Error of the Estimate & Sig. F Change \\
\hline 0.444 & 0.186 & 0.171 & 2.8981 & 0.000 \\
\hline
\end{tabular}

Predictors: (Constant), price, Aware, attitude

Buying and eco-friendly vehicle is based on the price, purchase awareness, attitude, subjective norms and environmental attitude as derived by a model summery. Since $\mathrm{R}^{2}$ is 0.171 , it can be conclude that $15.9 \%$ of variations in customers" purchase intention of buying an eco-friendly vehicle can be explained by price, awareness, attitude, subjective norms and environmental knowledge.

The impact behind purchase intention of these eco-friendly vehicles is widely based on awareness $(\mathrm{B}=0.318$, $\mathrm{p}<0.05)$, about eco-friendly vehicles, environmental knowledge $(\mathrm{B}=0.331, \mathrm{p}<0.05)$ and subjective norms $(\mathrm{B}=0.34$, $\mathrm{p}<0.05)$ as shown by a regression analysis. Therefore the hypotheses 1,2 and 4 are supported and accepted. The regression results are shown in Table 4. 
Table 4: Regression Analysis

\begin{tabular}{|l|l|c|c|c|l|}
\hline \multicolumn{1}{|c|}{ Variable } & Std. Beta & T & Sig & \multicolumn{1}{|c|}{ Results } \\
\hline 1. & Awareness of eco - friendly vehicles & 0.318 & 2.911 & 0.007 & Supported \\
\hline 2. & Environmental knowledge & 0.331 & 3.131 & 0.001 & Supported \\
\hline 3. & Attitude & 0.028 & 0.147 & 0.712 & Not supported \\
\hline 4. & Subjective norms & 0.343 & 3.732 & 0.000 & Supported \\
\hline 5. & Price perception & 0.140 & 1.603 & 0.143 & Not supported \\
\hline
\end{tabular}

\section{DISCUSSIONS}

There is a significant difference between eco-friendly vehicle and purchase intention among the vehicle users as found out in the study. The purchase intention significantly increases when the customers get the knowledge about the eco-friendly vehicles as found out in the study. This findings are also similar with the finding of (Ottman (2008) and Chen (2012) (Aman, 2012; Chahal, 2010; Suki et al., 2013). But it was found out that there is no significant relation between the product knowledge and purchase intention as found out by Karunanayake \& wnaninayake.

There should also be a significant knowledge about the environment when it comes to the change in the purchase intention of the user as found out in the study. The purchase intention of eco-friendly vehicle will only increase if one spreads the knowledge on how humans are destroying the environment with the pollution levels. These findings are similar with the finding of (Mostafa, 2007). (Barr, 2007), (Tilikidou, 2007) (Czap \& Czap, 2010).

The significant influence to buy the eco-friendly vehicles are the subjective norms and its suggested that the customers buying behavior can be influenced from other people as well. The significant factors influencing the buying intention towards eco-friendly vehicles are basically friends, relatives and social groups etc. Thus it's important that the influence coming from relatives, society and friends towards Eco-Friendly vehicles is significant towards the change in the purchase intentions. This finding also similar with (Albayrak, Aksoy, \& Caber, 2013) (Ohman, 2011) (Ooi, Kwek, \& Tan, 2012) Karunananayake \& Wanninayake. However it was found out by (Kumar, 2012), (Ham, Jeger, \& Ivković, 2015) and (Krueger, Reilly, \& Carsrud, 2000) that there is no significant influence on the purchase intention based on subjective norms.

The purchase intention towards buying an eco-friendly vehicle is not based on environmental knowledge and price as found out in this study. But it was also found out that there is no significant influence of environmental knowledge on the purchase intention of hybrid vehicles by Karunanayake \& wnnainayek (Gould \& Golob, 1998) (Kurani, Turrentine, \& Sperling, 1996), but in contrast to this (Akbar, Hassan, Khurshid, Niaz, \& Rizwan, 2014). (Jansson, Marell, \& Nordlund, 2009) found that there is significant influence on environmental attitude and purchase intention towards green products. In the studies done by $\mathrm{Ng} \&$ Paldino and contradictory with the findings of (Bang, Ellinger, Hadjimarcou, \& Traichal, 2000) (Griskevicius, Tybur, \& Van den Bergh, 2010) Karunanayake \& Wnaniyake and (Mostafa, 2007) the price perception is an insignificant factor on purchase decision.

\section{CONCLUSION \& RECOMMENDATIONS}

The perception of Indian customers towards eco-friendly vehicles and hybrid vehicles was found out in this study. The different variables of awareness about eco-friendly vehicles i.e. environmental knowledge, attitude, subjective norms and price perception were studied on the data collected from 125 vehicle owners from various cities in India. The positive influence on the purchase intention of Indian Customers is based on the awareness of eco - friendly vehicles, 
environmental knowledge and subjective norms.

On promotion of their products by the hybrid and eco-friendly car distributors this information can prove to very useful for them. It's important for the car distributors to make the customer aware about the advantages of buying a hybrid vehicle rather than gasoline vehicles and this can be done by educating the customers with the help of significant marketing campaigns focusing on the use of hybrid vehicles. The word of mouth marketing is also beneficial as it's the fastest way to send your information to family members, friends and the society. It becomes important for the NGO's and other environmental friendly organizations to spread the awareness about the eco-friendly vehicles as well as the government should also give incentives for eco-friendly vehicles.

\section{REFERENCES}

1. UNEP, “21 Issues for the 21st Century: Result of the UNEP Foresight Process on Emerging Environmental Issues,” 2012.

2. ] 2014 Online]. Available: http://www.ucsusa.org/our-work/global-warming/science-and-impacts/global-warmingimpacts\#.VzBF_IR97IW.

3. "Sunday Times," 04 March 2012. [Online]. Available: http://www.sundaytimes.lk/120304/BusinessTimes/bt25.html.

4. R. R. Heffner, K. S. Kurani and. T. Turrentine, "Symbolism and the adoption of fuelcell vehicles," World Electric Vehicle Association Journal 1, p. 24-31, 2007.

5. T. Turrentine and K. S. Kurani, “Car buyers and fuel economy?” Energy Policy, p. 1213-1223, 2007.

6. K. S. Gallagher and E. Muehlegger, "Giving Green to Get Green: Incentives and Consumer Adoption of Hybrid Vehicle Technology,” Faculty Research Working Papers Series, 2008.

7. J. Klein, “Why people Really buy Hybrids?” Topline Strategy Group Report, 2007.

8. G. Fryxell and C. Lo, "The influence on environmental knowledge and values on managerial behaviours on behalf of the environment: an empirical examination of managers in China," Journal of Business Ethics, vol. 46, pp. 45-59, 2003.

9. M. M. Mostafa, "Gender Differences in Egyptian Consumers' Green Purchase Behaviour: The Effects of Environmental Knowledge, Concern and Attitude," International Journal of Consumer Studies, pp. 220-229, 2007.

10. S. Barr, "Factors Influencing Environmental Attitudes and Behaviors," Environment \& Behaviour, pp. 435-73, 2007.

11. I. Tilikidou, "The Effects of Knowledge and Attitudes upon Greeks' Pro-Environmental Purchasing Behaviour," Corporate Social Responsibility and Environmental Management, pp. 121-34, 2007.

12. N. V. Czap and H. J. Czap, “An experimental investigation of revealed environmental concern,” Ecological Economics, p. 2033-2041, 2010 .

13. J. A. Roberts and D. R. Bacon, "Exploring the subtle relationships between environmental concern and ecologically conscious consumer behavior," Journal of Business Research, pp. 79-89, 1997.

14. H. K. Bang, A. E. Ellinger, J. Hadjimarcou and P. A. Traichal, "Consumer concern, knowledge, belief and attitude toward renewable energy: an application of the reasoned action theory," Psychology and Marketing, pp. 449-68, 2000 .

15. S. Bamberg, "How does environmental concern influence specific environmentally related behaviours? A new answer to an old question,” Journal of Environmental Psychology, pp. 21-32, 2003.

16. P. Kotler and G. Armstrong, Principles of Marketing, 2009. 
17. W. Akbar, S. Hassan, S. Khurshid, M. Niaz and M. Rizwan, “Antecedents Affecting Customer's Purchase Intentions towards Green Products," Journal of Sociological Research, 2014.

18. M.-S. Kim and J. E. Hunter, "Relationships among attitudes, behavioral intentions, and behavior - A meta-analysis of past research, Part 2," Communication Research, p. 331-364, 1993.

19. T. Albayrak, S. Aksoy and M. Caber, "The effect of environmental concern and scepticism on green purchase behaviour," Marketing Intelligence \& Planning, pp. 27 - 39, 2013.

20. N. Barber, P.-J. Kuo, M. Bishop and R. J. Goodman, "Measuring psychographics to assess purchase intention and willingness to pay,” Journal of Consumer Marketing, pp. 280 - 292, 2012.

21. P. S. Ellen, J. L. Wiener and C. C. Walgreen, "The Role of Perceived Consumer Effectiveness in Motivating Environmentally Conscious Behaviors,” Journal of Public Policy \& Marketing, pp. 102-117, 1991 .

22. J. Janssen, A. Marvell and A. Fordland, “. Elucidating green consumers: a cluster analytic approach on proenvironmental purchase and curtailment behaviors," Journal of Euromarkeing, pp. 245-267, 2009.

23. j. Gould and T. F. Golob, "Clean air forever? A longitudinal analysis of opinions about air pollution and electric vehicles," Transportation Research Part D, pp. 157-169, 1998.

24. K. S. Kurani, T. Turrentine and D. Sperling, "Testing Electric Vehicle Demand in "Hybrid Households" Using a Reflexive Survey,” Transportation Research Part D: Transport and Environment, p. 131-150, 1996.

25. A. Rivis and P. Sheeran, "Descriptive norms as an additional predictor in the theory of planned behaviour: A metaanalysis," Current Psychology, vol. 22, p. 218-233, 2003.

26. S. Taylor and P. Todd, "An integrated model of waste management behaviour: a test of household recycling and composting intentions,” Environment \& Behavior, 1995.

27. A. Biel and J. Thogersen, "Activation of social norms in social dilemmas: A review of the evidence and reflections on the implications for environmental behaviour,” Journal of Economic Psychology, vol. 28, p. 93-112, 2007.

28. B. Kumar, "of planned behaviour approach to understand the purchasing behaviour for environmentally sustainable products," Working paper series, No. 2012-12-08, 08122012.

29. T. Albayrak, S. Aksoy and M. Caber, "The effect of environmental concern and scepticism on green purchase behaviour," Marketing Intelligence \& Planning, vol. 31, pp. 27 - 39, 2013.

30. B. F. Stanton, X. Li,, M. M. Black, I. Ricardo, J. Galbraith, S. Feigelman and L. Kaljee, "Longitudinal stability and predictability of sexual perceptions, intentions, and behaviors among early adolescent African-Americans," Journal of Adolescent Health, vol. 18, p. 10-19, 1996.

31. M. Ham, M. Jeger and A. F. Ivković, "The role of subjective norms in forming the intention to purchase green food," Economic Research, pp. 738-748, 2015.

32. N. F. J. Krueger, M. D. Reilly and A. L. Carsrud, "Competing models of entrepreneurial intentions," Journal of Business Venturing, vol. 15, p. 411-432, 2000.

33. V. Griskevicius, J. M. Tybur and B. Van den Bergh, "Going green to be seen: status, reputation, and conspicuous conservation,” Journal of Personality \& Social Psychology, pp. 392-404, 2010.

34. R. R. Heffner, K. S. Kurani and T. S. Turrentine, "Symbolism in California's early market for hybrid electric vehicles," Transportation Research Part D, pp. 396-413, 2007. 
35. W. Y. Chua, A. Lee and S. Sadeque, "Why do people?" in Proceedings of Social Marketing Forum, Western Australia, 2010 .

36. Eurostat, "The EU in the world 2013 : A statistical portrait," 2013.

37. I. Ajzen, "The theory of planned behavior," Organizational behavior and human decision processes, pp. 179-211, 1991 .

38. I. Ajzen and M. Fishbein, Understanding attitudes and predicting social behaviour, Englewood Cliffs, Upper Saddle River New Jersey: Person Prentice Hall, 1980.

39. M. A. Alibeli and C. Johnson, "Environmental concern: a concern national analysis," Journal of International and Crosscultural Studies, pp. 1-10, 2009.

40. A. Aman, A. Harun and Z. Hussein, "The influence of environmental knowledge and concern on green purchase intention the role of attitude as a mediating variable,” British Journal of Art and Social Sciences, pp. 145-167, 2012.

41. Armitage, J. Christopher and M. Conner, "Efficacy of the theory of planned behaviour: A meta-analytic review," British journal of social psychology, pp. 471-499, 2001.

42. Casey,. J. Paul. Scott, "Environmental concern and behaviour in an Australian sample within an ecocentricanthropocentric framework," Australian Journal of Psychology, pp. 57-67, 2006.

43. M.-F. Chen, "Attitude toward organic foods among Taiwanese as related to health consciousness, environmental attitudes, and the mediating effects of a healthy lifestyle,” British Food Journal, pp. 165-178, 2009.

44. Corfman and P. Kim, “Comparability and comparison levels used in choices among consumer products," Journal of Marketing Research, pp. 368-374, 1991.

45. M. J. Cox, "Sustainable communication: a study of green advertising and audience reception within the growing arena of corporate social responsibility. Case study: British Petroleum," Earth \& environment, vol. 3, pp. 32-51, 2008.

46. J. D. DeLamater and D. J. Myers, Social psychology, United States: Cengage Learning, 2010.

47. Didier, Tagbata and S. Lucie, "Measuring consumer's willingness to pay for organic and Fair Trade products," International Journal of Consumer Studies, vol. 32, pp. 479-490, 2008.

48. D'Souza, Clare, M. Taghian and P. Lamb, “An empirical study on the influence of environmental labels on consumers," Corporate Communications: An International Journal, vol. 11, pp. 162-173, 2006.

49. Eckhardt and Andreas, "The significant others of subjective norm-A scientometric study of subjective norm in IS topjournals over two decades," in ECIS 2009 Proceedings, 2009.

50. Franke, Nikolaus and F. Piller, "Toolkits for user innovation and design: an exploration of user interaction and value creation," Journal of Product Innovation Management, pp. 401-415, 2004.

51. N. Franke and M. Schreier, "Product uniqueness as a driver of customer utility in mass customization," Marketing Letters, vol. 19, pp. 93-107, 2008 .

52. Hoch, J. Stephen and J. Deighton, “Managing what consumers learn from experience,” The Journal of Marketing, pp. 1-20, 1989 .

53. D. Horton and T. Turnage, Human Learning, Englewood Cliffs: Prentice-Hall, 1976.

54. M. S. Indati and H. A. Bekhet, "Highlighting of the Factors and Policies Affecting CO2 Emissions Level in Malaysian Transportation Sector," International Journal of Environmental, Chemical, Ecological, Geological and Geophysical 
Engineering, 2014 .

55. Irawan, Ronnie and D. Darmayanti, "The influence factors of green purchasing behavior: a study of University Students in Jakarta," in Proc. 6th Asian Business Research Conference, 2012.

56. Janssen,. A. Marco and J. Wander, "Stimulating diffusion of green products," Journal of Evolutionary Economics, p. 12, 283-306.

57. L. R. Kahle, “Observations: role-relaxed consumers: a trend of the nineties," Journal of Advertising Research, vol. 35, pp. 66-72, 1995.

58. F. G. Kaiser, M. Ranney, T. Hartig and P. A. Bowler, "Ecological behavior, environmental attitude, and feelings of responsibility for the environment," European psychologist, vol. 4, pp. 59-74, 1999.

59. T. R. Karunanayake and B. W. Wanninayake, "Impact of Key Purchasing Determinants on Purchase Intention of Hybrid Vehicle Brands in Sri Lanka, an Empirical Study,” Journal of Marketing Management, vol. 3, pp. 40-52, 2015.

60. H. R. Kaufmann, M. F. Panni and Y. Orphanidou, "FACTORS AFFECTING CONSUMERS'GREEN PURCHASING BEHAVIOR: AN INTEGRATED CONCEPTUAL FRAMEWORK,” Amfiteatru Economic, vol. 15, pp. 50-69, 2012.

61. Baumert,. A. Kevin, H. Timothy and J. Pershing, Navigating the numbers: Greenhouse gases and international climate change agreements, Washington, DC: World Resource Institute, 2005.

62. Lund, Henrik and W. Kempton, "Integration of renewable energy into the transport and electricity sectors through V2G," Energy policy, vol. 36, pp. 3578-3587, 2008.

63. A. P. Minton and L. R. Randall, "The effects of environmental concern on environmentally friendly consumer behavior: An exploratory study,” Journal of Business Research, vol. 40, pp. 37-48, 1997.

64. Norton, Bryan, R. Costanza and R. C. Bishop, "The evolution of preferences: whysovereign'preferences may not lead to sustainable policies and what to do about it," Ecological economics, vol. 24, pp. 193-211, 1998.

65. Öhman and Niclas, "Buying or lying-the role of social pressure and temporal disjunction of intention assessment and behavior on the predictive ability of good intentions," Journal of Retailing and Consumer Services, vol. 18, pp. 194-199, 2011.

66. Mei, J. Ooi, C. L. Kwek and H. P. Tan, “The antecedents of green purchase intention among Malaysian consumers," Asian Social Science, vol. 8, pp. 248-263, 2012.

67. L. G. Pelletier, K. M. Tuson and I. Green-Demers, "Why are you doing things for the environment? The motivation toward the environment scale (mtes) 1," Journal of applied social psychology, vol. 28, pp. 437-468, 1998 .

68. L. Rashotte, The Blackwell Encyclopaedia of Sociology, Hoboken: Blackwell, 2007.

69. P. W. Schultz, L. Zelezny and N. J. Dalrymple, "A multinational perspective on the relation between Judeo-Christian religious beliefs and attitudes of environmental concern," Environment and Behavior, vol. 32, pp. 576-591, 2000.

70. S. H. Schwartz, “Normative influences on altruisml," Advances in experimental social psychology, vol. 10, pp. 221-279, 1977 .

71. Sichtmann, Christina and. S. Susanne, "Limit conjoint analysis and Vickrey auction as methods to elicit consumers' willingness-to-pay: An empirical comparison,” European Journal of Marketing, vol. 11, pp. 1359-1374, 2007.

72. L. Steg, "Car use: lust and must. Instrumental, symbolic and affective motives for car use," Transportation Research Part A: Policy and Practice, pp. 147-162, 39. 
73. P. C. Stern, "New environmental theories: toward a coherent theory of environmentally significant behavior," Journal of social issues, vol. 56, pp. 407-493, 2000.

74. F. Voelckner, “An empirical comparison of methods for measuring consumers' willingness to pay,” Marketing Letters, vol. 17, pp. 137-149, 2006.

75. N. A. Wahid, E. Rahbar, S. S. Tan, "Factors influencing the green purchase behavior of Penang environmental volunteers," International Business Management, vol. 5, pp. 38-49, 2011.

76. Wertenbroch, Klaus and B. Skiera, "Measuring consumers' willingness to pay at the point of purchase," Journal of Marketing Research, vol. 39, pp. 228-241, 2002.

77. J. Williams, A. DeBenedictis, R. Ghanadan, A. Mahone, "The Technology path to deep greenhouse gas emissions cuts by 2050: the pivotal role of electricity,” Science, pp. 53-59, 2012.

78. J. A. Ottman, "The five simple rules of green marketing," Design management review, pp. 434-478, 2008.

79. Y.-S. Chen and C.-H. Chang, "Enhance green purchase intentions: The roles of green perceived value, green perceived risk, and green trust,” Management Decision, vol. 50, pp. 502-520, 2012 .

80. A. L. Aman, "The influence of environmental knowledge and concern on green purchase intention the role of attitude as a mendiating variable," British Journal of Arts and Social Science, vol. 7, p. 20469578, 2012.

81. H. Chahal and B. Madhu, "Significant components of service brand equity in healthcare sector," International journal of health care quality assurance, vol. 25, pp. 343-362, 2012.

82. N. M. Suki, “GREEN AWARENESS EFFECTS ON CONSUMERS'PURCHASING DECISION: SOME INSIGHTS FROM MALAYSIA," IJAPS, pp. 33-54, 2013.

83. R. K. T. Karunanayake and W. B. Wanninayake, "Impact of Key Purchasing Determinants on Purchase Intention of Hybrid Vehicle Brands in Sri Lanka, an Empirical Study,” Journal of Marketing Management, vol. 3, pp. 40-52, 2015.

84. A. PALADINO and S. NG, "Examining the influences of intentions to purchase green mobile phones among young consumers: An empirical analysis," ANZMAC, pp. 1-8, 2009. 
